\title{
„WEGGIERSKI ŚLAD”. Z WIOSNY LUDÓW (1848-1849) NA OBSZARZE KORONY ŚW. STEFANA DO POLSKIEGO POWSTANIA (1863-1863), CZ. I
}

Z kampanii wojennych lat I830-I863 Węgierska Wiosna Ludów zaangażowała najznaczniejszy procent spośród wyselekcjonowanej grupy (ok. II-23\%) późniejszych dowódców insurekcji styczniowej (237)․ Warto zatem przyjrzeć się bliżej ich zaangażowaniu w antyhabsburskie powstanie.

Historyczne granice Królestwa Węgier (Korona Św. Stefana) obejmowały Wielką Nizinę Węgierską, Słowację, Baczkę i Banat, Chorwację, Slawonię i Dalmację oraz Ruś Zakarpacką. Działania zbrojne (IX I848-IX/X I849 r.) objęły pierwsze 4 krainy. 20 kwietnia I848 r. rząd węgierski powołał do istnienia straż narodową, a I5 maja z inicjatywy premiera Lajosa Batthyanyego wezwano pod broń niezależne od armii habsburskiej wojsko węgierskie. Służyli tam pod nazwą „,honwedzi”, kalką językową niemieckiego określenia Landwehr (obrońca ojczyzny), ochotnicy zaciągnięci na 4 lata, posiadający mundury wzoru narodowego i żołd jak „cesarscy”. Choć armia bana Josipa Jelacica wkroczyła na Węgry 4 września, a 29 września I848 r. miało miejsce pierwsze zwycięstwo rewolucji pod Pakozd, początek wojny z Austrią przypada na 3 października I848 r., kiedy Ferdynand I bezprawnie rozwiązał węgierskie Zgromadzenie Krajowe.

Dla Polaków fakt, że Węgrzy skonfliktowali się z jednym z państw zaborczych niezależnie od tradycyjnych więzów przyjaźni sugerował, by zgodnie z politycznym interesem wesprzeć ich, najlepiej w formie wypracowanej na przestrzeni minionego półwiecza, czyli legionu³.

Jako główny organizator Legionu Polskiego przy armii węgierskiej zapisał się na kartach historii Józef Wysocki, nominowany na majora i dowódcę ,polsko-węgierskiego oddziału”, zwanego batalionem Wysockiego (I7/I8 listopada I848 r.)4. Już 20 października tr. Krajowy Komitet Obrony Ojczyzny, czyli powstańczy rząd węgierski zawarł z reprezentantami

\footnotetext{
Kryteria wyodrębnienia grupy to dowodzenie w co najmniej 1 bitwie: Leon Czachowski, Edward Dunajewski, Wiktor Dobrosielski, Narcyz Figietty, Franciszek Horodyński, Józef Jagmin, Antoni Jeziorański, Zygmunt Jordan, Karol Kalita, Walery Kozłowski, Walenty Lewandowski, Aleksander Matuszewicz, Zygmunt Miłkowski, Władysław Miśkiewicz, Ignacy Mystkowski, Julian Nadmiller, Władysław Józef Rucki, Stanisław Szumlański, Edmund Ślaski, Tomasz Wierzbicki, Leszek Wiśniowski, Józef Wysocki.

2 I. Kovacs, Polacy w węgierskiej Wiośnie Ludów 1848-1849. „Byliśmy z wami do końca”, Warszawa 1999, s. 66.

Z. Vesztroczy, Polski legion na Węgrzech w 1848-49 r., w: Pod wspólnym sztandarem. Polacy w węgierskiej Wiośnie Ludów, red. A. Nagy, A. Laszlo, Polskie Stowarzyszenie Kulturalne im. J. Bema na Węgrzech, Budapest 1999, s. 88-91.

4 E. Kozłowski, Generał Józef Bem, Warszawa 1958, s. 293; tenże, w: Zarys dziejów wojskowości do 1864 r., t. 1 , cz. 2, red. A. Grabski, Warszawa 1966, s. 473-474; J. Wimmer, Historia piechoty polskiej, Warszawa 1978, s. 558-
} 
komitetu filomadziarskiego we Lwowie umowę na sformowanie jednostki zbrojnej: ochotnicy otrzymali narodowy sztandar z mundurem (białe płaszcze z czerwonymi otokami, szaroniebieskie spodnie, czerwone rogatywki z baranim futerkiem $)^{5}$ i pozwolenie na posługiwanie się w szeregach ojczystym językiem. Przewidywano zaciąg I200 żołnierzy (batalion piechoty, szwadron ułanów, I-2 baterie artyleryjskie) ${ }^{6}$.

300-osobowy batalion (kompanie Ignacego Czernika i Konstantego Matczyńskiego) ${ }^{7}$ włączył się w oblężenie Aradu (4 grudnia I848 r.). Chociaż twierdza z I,5-tysięczną załogą feldmarszałka Johanna Bergera von der Pleisse należała do drugorzędnych w Imperium Habsburskim, jej zdobycie warunkowało zajęcie fortecy w Temesvarze, stolicy Banatu, co z kolei zmieniłoby układ sił tamże, w Baczce i Siedmiogrodzie. W działaniach oblężniczych uczestniczyły 2 bataliony węgierskich górali - Szeklerów, 2 bataliony honwedów oraz 4 kompanie debreczyńskiej Gwardii Narodowej pod dowództwem ppłk. Janosa Mariassyego ${ }^{8}$. Do kolumn szturmowych w natarciu grudniowym przeznaczono ochotników debreczyńskich, 4 kompanie 29 batalionu honwedów oraz pięć kompanii 30 batalionu. Ze względu na niedotrzymanie ciszy i niewystarczające $m$.in. ze względu na brak sprzętu bojowego przygotowanie akcji polski chrzest bojowy zakończył się porażką . Nowy komendant oblegających płk-inż. Miklos Gaal oraz komisarz rządowy Daniel Boczko doceniali zaangażowanie Polaków i ich komendanta. Do nich należała asekuracja przeprawy wodnej w starciu pod Nowym Aradem z grupą gen. Christiana Leiningena ( 3 bataliony piesze, pułk jazdy, I2 dział), zakończonym odrzuceniem Węgrów za rzekę i uzupełnieniem zaopatrzenia oraz garnizonu twierdzy (I4 XII I848 r. $)^{\text {I0 }}$.

Węgierskie dowództwo zgodziło się wtedy na organizację konnego szwadronu polskiego Władysława Ponińskiego ${ }^{\mathrm{II}}$ : umundurowanie wzoru austriackiego, czapki-konfederatki czerwone, chorągiewki przy lancach węgierskie, później mundur granatowy, rabaty mankietów i czapki w kolorze czerwonym ${ }^{\mathrm{I} 2}$. W tym właśnie oddziale znaleźć się miał m.in. członek

-562; A. Szmyt, Generał Józef Wysocki w stużbie wolności Polaków i Węrów, Olsztyn 2001, s. 136; I. Kovacs, Nieznani polscy bohaterowie powstania węgierskiego 1848-1849, Warszawa 2010, s. 42.

5 T. Iskrzycki, Mundury formacji polskich na Wegrzech $w$ latach 1848-1849, „Studia do Dziejów Dawnego Uzbrojenia i Ubioru Wojskowego", Kraków 1963, cz. 1, s. 71 i n.; Z. Miłkowski, Od kolebki przez życie, Kraków 1936, t. 1, s. 326; E. Kozłowski, Legion Polski na Wegrzech 1848-1849, Warszawa 1983, s. 98.

$6 \quad$ L. Russjan, Polacy i sprawa polska na Węgrzech w roku 1848-1849, Warszawa 1936, s. 97-98; E. Kozłowski, Generat Józef Bem, s. 286-287, tenże, Legion Polski, s. 32; J. Bułharyn, Rys wojny węgierskiej w roku 1848 i 1849 , Paryż 1852, s. 47-48; J. Wysocki, Pamiętnik generała... z czasów kampanii węgierskiej, Warszawa 1899, s. 6; J. Falkowski, Wspomnienia z roku 1848 i 1849, Warszawa 1908, cz. 1, s. 69; Z. Miłkowski, Od kolebki, t. 1, s. 276; J. Grabowiecki, Moje wspomnienia z emigracji od roku 1831 do 1854, spisane w Marsylii, Warszawa 1970, s. 145.

J. Wysocki, Pamiętnik, s. 12; I. Grabowiecki, Moje wspomnienia, s. 152.

8 E. Kozłowski, Legion Polski, s. 99-100; A. Szmyt, Generał Józef Wysocki, s. 139; I. Kovacs, Polacy w węgierskiej Wiośnie Ludów, s. 134-136; tenże, Nieznani polscy bohaterowie, s. 43 i n.

9 W. Rucki, Z pamiętników żołnierza, „Dziennik Literacki”, 1862, nr 49, s. 398; Z. Miłkowski, Od kolebki, t. 1., s. 280; A. Grochowalski, 1848 i 1849, Kampania na Węgrzech przez..., sztabu korpusu 3-go wegierskiego, B. Czartoryskich, Kraków rkps 5326, s. 312-313.

10 E. Kozłowski, Legion Polski, s. 100; J. Bułharyn, Rys wojny, s. 61; W. Poniński, Wspomnienia z lat ubiegłych: listy do moich synów, Kraków 1902, s. 31 i nn.

11 E. Kozłowski, Legion Polski, s. 99, 100-102; P. Wodziński, Wspomnienia żołnierza-tułacza (1848-1863), Lwów 1912, s. 24; K. Kalita, Ze wspomnień krwawych walki, Lwów 1913; Z. Miłkowski, Od kolebki, t. 1.

12 Według źródeł węgierskich mundury granatowe $\mathrm{z}$ białymi lampasami spodni, wyłogi kurty mundurowej i mankiety obszyte czerwoną wstążką, niebieska czapka z białą kitką i biało-niebieska chorągiewka na lancy. 
krakowskiej Gwardii Narodowej Julian Nadmiller ${ }^{13}$. Obecność legionistów pod murami twierdzy nie przyniosła większej zaprawy bojowej, bo poza dwoma wymienionymi starciami zajmowali się służbą garnizonową, patrolami, drobnymi potyczkami, a charakteryzowała ich słaba dyscyplina ${ }^{14}$.

Pod koniec grudnia I848 r. Lajos Kossuth mianował ppłk. Jerzego Bułharyna dowódcą naczelnym wszystkich legionów polskich na Węgrzech (oprócz legionu powstającego u boku gen. Józefa Bema w Siedmiogrodzie), co formalnie sankcjonowało stan dwuwładzy (konkurentem do stanowiska był Wysocki). Bułharyn stanął na czele niewielkiego oddziału tworzącego jądro 5 kompanii legionowej, w tzw. Korpusie Północnym podlegającym ministrowi wojny gen. Lazarowi Meszarosowi. Zreorganizowany korpus na Słowacji (Górne Węgry) liczył Io tys. żołnierzy (ponad 8000 piechurów, I60o kawalerzystów, 34 działa).

Przeciwko galicyjskiemu korpusowi gen. dywizji hr. Franza Schlicka von Bassano und Weisskirchen ( 3 brygady - tj. 6,7-8 tys. żołnierzy) podkomendni Bułharyna walczyli w przegranych starciach pod Koszycami (4 grudnia) oraz Szinnye (22 grudnia I848 r.), następnie o odzyskanie Koszyc (4 stycznia I849 r.) ${ }^{15}$. W spieszonym ze względu na niedostatek koni szwadronie 2 pułku huzarów Władysława Tchórznickiego z dywizji płk Sandora Pulszky’ego (IO-I2 tys. ludzi, I5 dział) znajdował się już Antoni Jeziorański ${ }^{16}$. Jego debiut bojowy wiązał się ze wspomnianą obroną Góry Koszyckiej, kiedy przeciwnatarcie bezkonnych polskich ułanów i 42 batalionu honwedów uratowało dywizyjną artylerię ( 36 dział z 660-osobową załogą) walczącą obok 2-3 honwedzkich batalionów, kilku jednostek pieszej gwardii narodowej, ok. I200 huzarów, ok. I90 konnych gwardzistów ${ }^{17}$. Owi piesi ułani pod Barcą zorganizowali zasadzkę na austriacką kawalerię pościgową pod dowództwem mjr. Concorregio z pułku szwoleżerów i kpt. sztabowego Sudiera (II grudnia I848 r.) ${ }^{18}$.

Z rozbitego na początku I849 r. Korpusu Północnego podwładni Bułharyna przeszli do utworzonego na jego bazie Korpusu Górnej Cisy płk. Georgy’ego Klapki z dwóch dwubrygadowych dywizji i osobnej brygady: Bułharynowi podlegały brygady mjr. Istvana Zako i ppłk. Władysława Tchórznickiego (2 batalion mjr. Tadeusza Idzikowskiego - 3 kompanie, szwadron 2 pułku ułanów, bateria 4 dział kpt. Grabowieckiego - I20 bagnetów i Ioo szabel, inne źródła podają, iż Polaków było 350-380). Razem korpus - 6IIo bagnetów, 7I5 szabel i 34 działa $^{19}$. Polscy ułani mieli obecnie białe rabaty na granatowych kurtach mundurowych, czapki wzoru armii Królestwa Polskiego, proporczyki w barwach węgierskich, następnie polskich, z kolorem pułku ${ }^{20}$.

\footnotetext{
13 E. Kozłowski, Julian Natmiller (1823-1903), PSB, t. 23, Kraków 1977, s. 618-619.

14 J. Bułharyn, Rys wojny, s. 58; W. Rucki, Z pamiętników żotnierza, s. 401; W. Poniński, Wspomnienia, s. 30; Z. Miłkowski, Od kolebki, t. 1, s. 286-287; S. Schnur-Pepłowski, Polacy $i$ Węgrzy. Opowieść dziejowa z lat 1848 i 1849, Lwów 1896, s. 120-121; A. Grochowalski, 1848 i 1849, Kampania na Wegrzech, s. 310-311.

15 E. Kozłowski, Legion Polski, s. 86.

16 E. Kozłowski, Antoni Jeziorański (1821-1882), PSB, t. 11, Kraków 1964-1965, s. 215-216.

17 Ibidem, s. 87.

18 E. Kozłowski, Legion Polski, s. 95; I. Kovacs, Polacy w węgierskiej Wiośnie Ludów, s.162-169; A. Jeziorański, Pamiętniki jenerała... od roku 1848 do 1863, Lwów 1880, s. 25.

19 E. Kozłowski, Legion Polski, s. 92-96, 112, 153-154. Inna wersja liczebności korpusu: 7925 bagnetów, 695 szabel.

20 I. Grabowiecki, Moje wspomnienia, s. 151; A. Langie, Pamiętniki niedoli... z lat 1849-1856, Kraków 1896, s. 20.
} 
Wkrótce odbyła się niekorzystna dla jazdy Tchórznickiego potyczka pod Szanto (I9 I), kiedy to mimo wsparcia kompanii Hipolita Żółtowskiego porzuciła pozycję obronną, potem bój pod Tarczalem u podnóża Góry Tokajskiej (2I stycznia). Dwie brygady Schlicka wzmocnione dywizją gen. Franza Schulziga mierzyły się o Górę Teresy (Teresienberg) z korpusem nadcisańskim, a decydującą o triumfie rolę odegrała 2,5-tysięczna dywizja Bułharyna. Tchórznicki wraz z kawalerzystami znalazł się wśród wyróżnionych przez podkreślającego zasługi bitewne Polaków Klapkę, wśród licznie awansowanych był ppor. Jeziorański. W lutym Tchórznicki rozpoczął formowanie oddziału lansjerów w Nyiregyhaza, a ze względu na brak wolnych stanowisk oficerskich Jeziorański przeszedł do kompanii kapitana Antoniego Wieruskiego, 2 batalionu Idzikowskiego, działającego na froncie środkowowęgierskim ${ }^{21}$. Oficerem szwadronu huzarów I galicyjskiego pułku Coburg, który wszedł do korpusu płk. Klapki już jako jednostka honwedzka, następnie przydzielonym w maju I849 r. do obleganej przez armię Jelacica twierdzy Petroveradin (Petervarad, Novi Sad) w południowej Baczce, starającym się o przeniesienie pod komendę gen. Dembińskiego, był Tomasz Wierzbicki ${ }^{22}$.

U schyłku stycznia I849 r. Kossuth wyznaczył gen. Henryka Dembińskiego naczelnym wodzem wojsk węgierskich (24602 bagnety i szable, 75 dział, w lutym 37 tys. i I20 dział $)^{23}$. Jego adiutantem został Zygmunt Jordan ${ }^{24}$. W pogoni korpusu Klapki za Schlickiem uczestniczyła dywizja Bułharyna. Batalion mjr. Idzikowskiego przy wsparciu 2 kompanii węgierskich i 4 dział w asekuracji szwadronu huzarów odznaczył się w boju ze strażą tylną Austriaków, m.in. zdobyciem podpalonego mostu na rzece Hernada pod Hidasnemeti (8 lutego) ${ }^{25}$. Poza Jordanem brał w tych działaniach udział Jeziorański, podobnie jak w zakończonej klęską 30-tysięcznego wojska węgierskiego dwudniowej batalii pod Kapolną (26-27 lutego). Pierwszego dnia I20-osobowy 2 batalion legionu z 4 kompaniami węgierskimi, 4 działami i szwadronem huzarów bronił wąwozu Szirok przed 3 batalionami brygady gen. Kriegerna $\mathrm{z}$ artylerią, przy wycofywaniu się, pozostawiając niezniszczone mosty na Tarnie, drugiego osłaniał przeprawę cofającego się korpusu przez most na potoku Lasko pod Kerecsend ${ }^{26}$.

Szybko linia wojskowej kariery Józefa Wysockiego zaczęła piąć się ku górze: od stycznia występował w stopniu podpułkownika, w lutym otrzymał nominację na dowódcę jednej z brygad (dwukompanijny batalion polski, jednoszwadronowy pułk jazdy, 3 i 9 batalion

21 J. Helfert, Geschichte Osterreichs vom Ausgange des Wiener October-Ausfstandes 1848. Der ungarische Winterfeldzug Und die octroirte Verfassung, t. 4, cz. 2, Prag-Leipzig 1886, s. 165, 489; R. Kissling, Die Revoluton im Kaisertum, t. 2, Vienna 1948, s. 37; E. Kozłowski, Legion Polski, s. 157, 159; 160-165; A. Jeziorański, Pamiętniki jenerała, t. 1, s. 44-56; J. Szyc, Legiony polskie na Węgrzech. Wspomnienia oficera tychże Legionów, Poznań 1850, s. 24; G. Klapka, Der Nationalkrieg in Ungarn und Sienburgen in den Jahren 1848 und 1849, t. 1, Leipzig 1851, s. 195-196; J. Bułharyn, Rys wojny, s. 97-102; J. Wysocki, Pamiętnik, s. 23-25; J. Grabowiecki, Moje wspomnienia, s. $163-164$.

22 I. Kovacs, Polacy w węgierskiej Wiośnie Ludów, s. 527; J. Łątka, Słownik Polaków w Imperium Osmańskim i Republice Tureckiej, Warszawa 2005, s. 159.

23 L. Russjan, Polacy i sprawa, s. 48; E. Kozłowski, Legion Polski, s. 175; B. Szyndler, Henryk Dembiński 1791-1864, Warszawa 1984, s. 272; G. Klapka, Der Nationalkrieg, t. 1, s. 207; A.F. Danzer, Dembiński In Ungarn, Vienna 1873, t. 1, s. 108-109.

24 Zygmunt Jordan (1824-1866), PSB, t. 11, Kraków 1964-1965, s. 290.

25 E. Kozłowski, Legion Polski, s. 181; A. Danzer, Dembiński in Ungarn, t. 1, s. 100; A. Jeziorański, Pamiętniki, t. 1, s. 52-53; I. Grabowiecki, Moje wspomnienia, s. 167.

26 E. Kozłowski, Legion Polski, s. 188-194; B. Szyndler, Henryk Dembiński, s. 273-275; J. Bułharyn, Rys wojny, s. 140, 159-160; G. Klapka, Der Nationalkrieg, t. 1, s. 249; A. Danzer, Dembiński in Ungarn, t. 1, s. 89-90, 179-180; A. Jeziorański, Pamiętniki, t.1, s. 56-57; J. Wysocki, Pamiętnik, s. 37-38; I. Grabowiecki, Moje wspomnienia, s. 169-170; A. Grochowalski, Kampania na Wegrzech, s. 330-332. 
honwedów) banackiej dywizji gen. Janosa Damjanicha, w marcu komendę dywizji III korpusu armii węgierskiej ( 6 batalionów honwedów, 2 batalion polski, 4 ochotnicze kompanie strzelców pieszych, 4 szwadrony huzarów 2 pułku Hannover, szwadron ułanów Władysława Ponińskiego i 3 baterie artyleryjskie ${ }^{27}$.

Rozbudowany do ponad 600-osobowych rozmiarów 5-kompanijny legion pod bezpośrednim zwierzchnictwem kpt Ignacego Czernika (uzupełniony 2 kompaniami dawnego pułku strzeleckiego Henryka Rembowskiego, obecnie pod kierownictwem Antoniego Wieruskiego i kompanię Hipolita Żołtowskiego z górnowęgierskiego batalionu Idzikowskiego) podczas kampanii wiosennej trafił do jednej z najlepszych w całej armii powstańczej dwubrygadowej dywizji Wysockiego w korpusie Damjanicha ${ }^{28}$. Polski batalion, 3 batalion 60 pułku Waza i 42 batalion honwedów tworzył brygadę płk. Ede Czillicha, zaś na brygadę mjr. Karoly’ego Leiningena-Westerburga składały się 3 batalion I9 pułku Schwarzenberga i 3 batalion honwedów, z uzupełnieniem 6 szwadronów 3 pułku huzarów i polskiego szwadronu ułanów.

Polacy dali o sobie znać podczas wiosennej ofensywy rewolucyjnych Węgier. Pod Szolnok (5 marca I849) III korpus w decydujący sposób wsparł dywizję płk Karoly’ego Vecseya walczącego z oddziałami gen. Franza Ottingera. Brygadier Wysocki kierował prawym skrzydłem linii bojowej (batalion polski, 3 batalion honwedów, bataliony piechoty liniowej 60 pułku Wasa i I9 pułku Schwarzenberg) ${ }^{29}$. Szturm miasta, w którym uczestniczył Wysocki, rozpoczął polski batalion, a za nim podążyły pozostałe. Najwspanialszym momentem zmagań okazała się szarża szwadronu I20 lansjerów Ponińskiego na osłaniający odwrót armii cesarskiej II pułk dragonów Franz Jozsef ( 2 dywizjony dragonów, strzelcy piesi i artyleria), której przykład stopniowo inspirował kawalerzystów węgierskich (dwa szwadrony 2 pułku huzarów, szwadron 3 pułku huzarów, dwa kolejne szwadrony 2 pułku huzarów). Dowódcą pieszego plutonu zdobywającego most na Cisie i umożliwiającego dalszy pościg był por. Józef Jagmin ${ }^{30}$. Generalny odwrót nieprzyjaciela otworzył możliwość natarcia na Budę i Peszt. Poza piątką odznaczonych Orderami Zasługi III klasy polskich oficerów awans na pułkownika otrzymał Wysocki.

Pod Hatvan (2 kwietnia) podczas udzielania pomocy VII korpusowi gen. Andrasa Gaspara przeciw III korpusowi Schlicka brygadier Wysocki wykazał się wbrew oficjalnym dyrektywom przytomnością umysłu. Dzięki temu powstrzymano Austriaków, a wskutek kontruderzenia gen. Gaspara i batalionu Wysockiego doszło do odbicia wzgórza i miasta ${ }^{31}$. $\mathrm{Na}$ czele swego rodzaju oddziału szturmowego mimo ostrzału austriackich kartaczy wykazywał się szaleńczą brawurą Jagmin, z Zygmuntem Miłkowskim u boku² ${ }^{32}$ Z czołowym plutonem i naśladującymi go polskimi kompaniami piechoty, przebiegając po belkach mimo

\footnotetext{
27 A. Kozłowski, Legion Polski, s. 104; A. Szmyt, Generał Józef Wysocki, s. 141; J. Bułharyn, Rys wojny, s. 194; W. Poniński, Wspomnienia, s. 39.

28 Według samego Wysockiego formacja otrzymała znaki honorowe za waleczność.

29 E. Kozłowski, Legion Polski, s. 206; według A. Szmyta J. Wysocki dowodził 1. linią szyków powstańczych.

30 E. Kozłowski, Legion Polski, s. 206-209; I. Kovacs, Nieznani polscy bohaterowie, s. 49, 139; A. Szmyt, Generat Józef Wysocki, s. 149-150; J. Bułharyn, Rys wojny, s. 95-98, 194, 200-201; A. Jeziorański, Pamiętniki jenerała, s. 60-62; J. Wysocki, Pamiętnik, s. 39; W. Poniński, Wspomnienia, s. 42-43; K. Kalita, Ze wspomnień, „Biblioteka Warszawska", 1912, s. 241-242; Z. Miłkowski, Od kolebki, t.1, s. 296-297.

31 E. Kozłowski, Legion Polski, s. 211-212; J. Wysocki, Pamiętnik, s. 47-48; Z. Miłkowski, Od kolebki, t. 1, s. 303-304.

32 S. Kieniewicz, M. Małecki, Zygmunt Miłkowski (1824-1915) ps. Tomasz Teodor Jeż, PSB, t. 10, Kraków 1963
} 
zerwanych przęseł opanował most na Zagyvie. Zajął pozycję daleko za mostem, odmawiając opuszczenia przyczółka, za co został zresztą czasowo aresztowany.

Pod Tapiobicske (4 kwietnia) w trakcie bitwy spotkaniowej korpusu gen. Klapki z brygadami piechoty gen. Daniela Raszticha oraz jazdy płk. Leopolda Sternberga z I korpusu bana Jelacica zwycięstwo strony węgierskiej umożliwiło nadejście korpusu Damjanicha, przy czym Polacy z przejmującej ciężar walki dywizji Wysockiego (włączenie się do boju 3 batalionu I9 pp, 3 batalionu 60 pp oraz dwóch batalionów honwedów) w przeciwnatarciu zdobyli most na rzece Tapio i całą groblę. W pościgu uczestniczył m.in. szwadron ułanów Ponińskiego ${ }^{33}$.

Pod Isaszeg (6 kwietnia) kontynuujące pościg węgierskie korpusy dopadły nieprzyjaciela: Klapka natarł na prawe skrzydło korpusu Jelacica, a Damjanich na skrzydło lewe, posługując się dywizją gen. Karoly’ego Knezicia, podczas gdy dywizja Wysockiego pozostawała w rezerwie. Niespodziewany atak na tyłach korpusu Schlicka w rozciągających się w pobliżu pobliskiego wzgórza leśnych ostępach (tzw. Królewskie Lasy) powstrzymali podkomendni Wysockiego najpierw z batalionem Wasa dowodzonym przez kpt. Adama Hoszowskiego, potem z brygadą Leiningena, wreszcie z przybyłym korpusem gen. Lajosa Aulicha, dzięki czemu gen. Klapka odparł wroga ${ }^{34}$. Była to najważniejsza wiktoria kampanii wiosennej. W miejscowości Godollo podczas defilady triumfującego wojska przed Kosstuthem dyktator zdjął lekko uchylany kapelusz i trzymał w ręku aż do końca przemarszu dywizji Wysockiego, a przede wszystkim polskich legionistów i ułanów ${ }^{35}$.

Pod Wacowem nad Dunajem (Io kwietnia) w trakcie konfrontacji korpusów Klapki oraz Damjanicha z dywizją gen. Hermanna von Ramberga, zastępowanego przez gen. bryg. Christiana Gotza (zabitego podczas starcia przez Polaków), a następnie gen. bryg. Feliksa Jablonovskiego, lewoskrzydłowej formacji Wysockiego przypadł w udziale szturm miasta. Kluczowy moment stanowiło natarcie na kamienny most nad potokiem Gombas z wymownym epizodem przejmowania legionowego sztandaru z rąk padających żołnierzy. Tenże sztandar miał później na wniosek gen. Gorgeia być zgłoszony ministrowi wojny do odznaczenia Orderem Zasługi III klasy. Polski batalion rozproszył austriackich rakietników, a następnie oparł się szarży konnicy. Za porażkę dymisję otrzymał głównodowodzący armii habsburskiej, feldmarszałek Alfred zu Windischgraetz ${ }^{36}$.

$\mathrm{Z}$ polecenia dowódcy korpusu płk Wysocki sprawować miał dowództwo nad siłami powstańczymi w I fazie bitwy pod Nagysallo (I9 kwietnia). W centrum stał III korpus z dywizją Wysockiego, początkowo gen. Damjanich znajdował się poza placem boju, a na lewym skrzydle spóźniał się VII korpus gen. Gaspara. Ponieważ I korpus Klapki wyparł

33 E. Kozłowski, Legion Polski, s. 212-213; A. Szmyt, Generat Józef Wysocki, s. 153-154; T. Bułharyn, Rys wojny, s. 228-229; J. Wysocki, Pamiętnik, s. 49; W. Poniński, Wspomnienia, s. 46-47; Z. Miłkowski, Od kolebki, t. 1, s. 305-306; A. Grochowalski, Kampania na Wegrzech, s. 347.

34 E. Kozłowski, Legion Polski, s. 214-215; A. Szmyt, op. cit., s. 154-155; J. Szyc, Legiony polskie, s. 34, 36-37, 45; J. Bułharyn, Rys wojny, s. 232-232; A. Jeziorański, Pamiętniki jenerała, s. 65; J. Wysocki, Pamiętnik, s. 51-52; Z. Miłkowski, Sylwety emigracyjne, Lwów 1904, s. 130; tenże, Od kolebki, t. 1, s. 306-207. Literacki opis bitwy znajduje się w Lalce Bolesława Prusa (Pamiętnik starego subiekta).

35 E. Kozłowski, Legion Polski, s. 209, 215; K. Kalita, Ze wspomnień, s. 243.

36 E. Kozłowski, Legion Polski, s. 217; I. Kovacs, Polacy w węgierskiej Wiośnie Ludów, s. 406-408; A. Szmyt, Generał Józef Wysocki, s. 155; J. Szyc, Legiony polskie, s. 39; J. Bułharyn, Rys wojny, s. 235; J. Wysocki, Pamiętnik, s. 53; W. Poniński, Wspomnienia, s. 47. 
wroga z Nagysallo Wysocki podjął walną próbę jego wsparcia, zajmując m.in. samą wieś ${ }^{37}$. Udało się bez problemu powstrzymać natarcie batalionów cesarskich. Według jednego ze źródeł Polacy dzierżyli prym pierwszeństwa w natarciu na bagnety, według innego zapisali się chwalebnie jako uczestnicy walk ulicznych. Konsekwencją zwycięstwa było zajęcie naddunajskiej fortecy Komarno (22 kwietnia).

Dywizja Wysockiego wzięła udział w odrzuceniu przeciwnika spod twierdzy Komarno (27 kwietnia) - po przeprawieniu się mostem pontonowym przez Dunaj przez armię gen. Gyorgeya (dywizje Knezicha, Wysockiego i Klapki) i dalszym pościgu z udziałem ułanów Ponińskiego aż pod Gyor na drodze do Wiednia ${ }^{38}$. Odnotowano siódme zwycięstwo Legionu Polskiego: Ten skromny oddziałek nie byt w stanie przeważyć losów wojny, ale w kilku wypadkach brawura polskiego piechura i ułana zadecydowała o wynikach bitwy39. Następnie batalion Czernika i szwadron Ponińskiego pełniły służbę pomocniczą podczas oblężenia Budy, lecz nie wzięły udziału w szturmie generalnym, odesłane do Miszkolca ${ }^{40}$.

Dzięki powyższym zasługom wraz z nominacją generalską powierzono Wysockiemu pełnomocną komendę wszystkich jednostek polskich na Węgrzech, rozproszonych po korpusach walczących z habsburskimi siłami zbrojnymi (9 maja) ${ }^{41}$. Prace związane z organizacją głównej formacji polskiej odbywały się w Miszkolcu. W czerwcu na legion składały się 4 bataliony piechoty, dwa pułki ułanów (każdy z 3 szwadronów) oraz kompania saperów ${ }^{42}$. W piechocie służyło do 2305 ochotników, w kawalerii do 560 jeźdźców, w artylerii ok. 75, w niewielkim oddziałku ok. 8o, łącznie ok. 3 tysiące legionistów. Legion odkomenderowano do dywizji Tadeusza Bułharyna (dwubrygadowa 19 Armee-Division) w IX korpusie gen. Henryka Dembińskiego ${ }^{43}$.

W dwóch największych miastach Galicji funkcjonowały centralne komitety filomadziarskie, z filiami w mniejszych ośrodkach. Akcja przerzutu ochotników przebiegała wytyczonymi szlakami, z rozwiniętą siecią punktów zbornych i etapowych, a także z pomocą przewodników na pograniczu. Przedzierano się przeważnie w kilku- kilkunasto-kilkudziesięcioosobowych grupach ${ }^{44}$. Werbunek agitatorów do Legionu Wysockiego przynosił

\footnotetext{
37 A. Szmyt, Generat Józef Wysocki, s. 157-158; E. Kozłowski, Legion Polski, s. 218-219 - wg niego Damjanich był ciągle obecny; I. Kovacs, Polacy w węgierskiej Wiośnie Ludów, s. 412; G. Klapka, Der Nationalkrieg, t. 1, s. 241; Z. Miłkowski, Od kolebki, t. 1, s. 313; J. Wysocki, Pamiętnik, s. 58-61.

38 I. Kovacs, Polacy w węgierskiej Wiośnie Ludów, s. 417; A. Szmyt, Generał Józef Wysocki, s. 158-159; E. Kozłowski, Legion Polski, s. 220-221; J. Szyc, Legiony polskie, s. 44; A. Jeziorański, Pamiętniki jenerała, s. 67; W. Poniński, Wspomnienia, s. 48; Z. Miłkowski, Od kolebki, t. 1, s. 318.

39 E. Kozłowski, Legion Polski, s. 221.

40 E. Kozłowski, Legion Polski, s. 221; Z. Miłkowski, Od kolebki, t. 1, s.319.

41 E. Kozłowski, Legion Polski, s.136, 144; I. Kovacs, Polacy w węgierskiej Wiośnie Ludów, s. 477-478; A. Szmyt, Generał Józef Wysocki, s. 161-162; J. Wysocki, Pamiętnik, s. 65.

42 E. Kozłowski, Legion Polski, s. 141-145; I. Kovacs, Nieznani polscy bohaterowie, s. 53.

43 E. Kozłowski, Legion Polski, s. 223-225.

44 L. Russjan, Polacy i sprawa, s. 90; E. Kozłowski, Legion Polski, s. 45-48, 54-58; P. Wodziński, Wspomnienia, s. 9, 16; Z. Miłkowski, Od kolebki, s. 271; I. Grabowiecki, Moje wspomnienia, s. 141-142; J. Rucki, Opowiadanie oficera.., „Dziennik Polski”, Poznań 1849, nr 155; tenże, Z pamiętników żotnierza, s. 393; A. Jeziorański, Pamiętniki, t. 1, s. 3-4, 20; W. Poniński, Wspomnienia, s. 26; J. Sokulski, W kraju i nad Bosforem, Wrocław 1951, s. 192; S. Łusakowski, Pamiętniki zdeklasowanego szlachcica, Warszawa 1952, s. 192.
} 
efekty, pozyskiwano jeńców polskiego i ukraińskiego pochodzenia. Mimo to dochodziło do bratobójczych spotkań z piechurami pułków 9, IO, I2, 40 i $58^{45}$.

Dezerterem był Karol Kalita ${ }^{46}$. Służył w zdominowanym przez polskich rekrutów 9 pułku piechoty ze Stryja, szykował się do wyprawy na Węgry już od grudnia I848 r., jednak otrzymał urlop dla kontynuowania studiów. Ostatecznym powodem ucieczki miał się stać wpięty w krawat, dostrzeżony przez oficera służby celnej znak polskiego orła. Z pomocą komitetu werbunkowego w Jarosławiu na początku maja I849 r. przekroczył kordon galicyjski pod Łupkowem, uciekając przed formacją Landsturmu i kierując się do Miszkolca, gdzie trafił do 3 szwadronu I pułku lansjerów ${ }^{47}$. Również dzięki wsparciu ze strony sieci komitetów, od lwowskiego poczynając, Zygmunt Miłkowski z II towarzyszami przybył na Węgry. Ojciec chrzestny polskiego ruchu narodowego zaczynał jako podporucznik 3 batalionu. Jednym członków komisji organizacyjnej Legionu Wysockiego został por. Franciszek Ksawery Horodyński ${ }^{48}$, dowódca I kompanii 3 batalionu.

W zreorganizowanym 2 batalionie Wieruskiego walczył jako jego adiutant Jeziorański. Podporucznikiem baterii artyleryjskiej mianowano Walerego Lewandowskiego, o którym wiadomo, że unikając aresztowania za działalność w rzeszowskiej Radzie Narodowej, uciekł na Węgry, a w ostatnich dniach walk uratował od samosądu kilku jeńców rosyjskich, w tym kpt. Nikołaja Drejera ${ }^{49}$. W Legionie Wysockiego znalazł się również Walery Kozłowski ${ }^{50}$.

W 2 pułku lansjerów legionowych ppłk. Władysława Tchórznickiego natrafiamy na rtm. Wiktora Dunajewskiego, brata Edwarda ${ }^{51}$. Obaj uciekli z Galicji na Węgry, można domniemywać, że Edward służył z nim w tej jednostce.

Józef Wysocki otrzymał nominację na generała brygady (3 VI), komenderując przejętym po dymisji gen. Dembińskiego ${ }^{52}$ IX korpusem honwedów, dywizją rezerwową ppłk. Lajosa Kazinczy'ego, jednostką ruchomą mjr. Armina Gorgeya i legionem polskim, tworzącymi teraz Armię Północną. Na polską formację składały się 3 piesze, pięciokompanijne bataliony (każdy po cztery kompanie liniowe i strzelecka po 800 ludzi), dwa 4-szwadronowe pułki ułanów, 2 półbaterie artyleryjskie, kompania saperów ${ }^{53}$.

Niebawem otrzymał Wysocki stanowisko Obercommandanta IX korpusu i samodzielnej dywizji Kazinczy'ego, wymagające oprócz osobistego kierowania operacjami, regularnego

45 E. Kozłowski, Gen. Józef Bem, s. 470, 473; tenże, Legion Polski, s. 166-167, 284-285; M. Baczkowski, Galicjanie w armii austriackiej wobec wydarzeń lat 1848-1849, w: Galicja i jej dziedzictwo, t. 12, Galicja w 1848 roku, red. W. Bonusiak, J. Buszko, Rzeszów 1999, s. 94-95; Geschichte des k.u.k. Infanterie,-Regiment Erherzog Wilhelm $n r$ 12, t. 2, Wien 1880, s. 202-205, 272-276.

46 L. Ratajczyk, Karol Kalita ps. Rębajło (1830-1919), PSB, t.11, Kraków 1964-1965, t. 11, s. 41.

47 K. Kalita, Ze wspomnień, s. 244.

48 Franciszek Ksawery Horodyński (1811-1863), PSB, t. 10, Kraków 1963, s. 3; E. Kozłowski, Legion Polski, s. 146-147; J. Wysocki, Pamiętnik, s. 145.

49 M. Tyrowicz, Walenty Lewandowski (1824-1916), PSB t. 18, Kraków 1973, s. 211-213; I. Kovacs, Nieznani polscy bohaterowie, s. 183; J. Wysocki, Pamiętnik, s. 145.

50 J. Wysocki, Pamiętnik, s. 149.

51 M. Tyrowicz, Edmund Dunajewski (?-1863), PSB, t.6, Kraków 1947, s. 465; A. Zieleniecki, D. Kacnelson, Udział Polaków z Galicji w powstaniu węgierskim 1848-1849 r., „Rocznik Naukowo-Dydaktyczny Wyższej Szkoły Pedagogicznej w Rzeszowie”, 1982, s. 71; I. Kovacs, Polacy w węgierskiej Wiośnie Ludów, s 384; J. Wysocki, Pamiętnik, s. 147.

52 B. Szyndler, Henryk Dembiński, s. 281-282.

53 E. Kozłowski w: Zarys dziejów wojskowości polskiej do 1864 r., t. 2, cz. 2, s. 473; tenże, Legion Polski, s. $134-$ -135, 237-238; A. Szmyt, Generał Józef Wysocki, s. 166. 
wydawania dyspozycji generałom Aristidowi Dessewffyemu i Kazinczyemu, i sporządzania regularnych meldunków ${ }^{54}$. 22 czerwca zamiast przeciwstawienia się nieprzyjacielowi w okolicy Preszowa podjął on decyzję o rozpoczęciu zbrojnego odwrotu przed wkraczającymi przez przełęcze karpackie na Węgry korpusami interwencyjnych sił carskich (II, III, IV). Siły w dyspozycji Wysockiego (2 bataliony strzelców mjr. Lajosa Cornidesza, 9 batalionów honwedów, 2 batalion Legionu Polskiego, batalion Lajosa Beniczkyego, jednostka specjalna A. Gorgeya, I2 kompanii ochotniczych w 2 batalionach, 6 szwadronów huzarów, szwadron 2 pułku ułanów, szwadron obrony krajowej, 3I dział i 3 rakietnice) z dywizją Kazinczyego obliczano na ok. 2I tys. żołnierzy. Bezpośrednio mu zagrażające rosyjskie korpusy II gen. Pawła Kuprianowicza i IV gen. Michaiła Czeodajewa liczyły w 80 batalionach piechoty, 64 szwadronach jazdy i I2 sotniach kozackich 7I tys. bagnetów, 9,5 tys. szabel oraz 288 dział, co oznaczało czterokrotną dysproporcję piechoty i jazdy, a pięciokrotną w artylerii. Planowaną pod Koszycami obronę uniemożliwiła próba oskrzydlenia wymuszająca dalsze cofanie się. Obercommandant zakładał opóźnianie marszu interwentów przy jednoczesnym zachowaniu substancji ludzkiej, utrudnionym wobec ryzyka rozprężenia i dezercji z szeregów5 ${ }^{55}$. Eligiusz Kozłowski zauważył, że pozbawiony kompetencji dowódczych stopnia operacyjnego Wysocki przez 2 tygodnie prowadził przez $250 \mathrm{~km}$ bezustanny odwrót, co oznaczało oddanie bez walki północnych połaci Węgier, przy $1 / 4$ strat własnych ${ }^{56}$. Wysocki działał zgodnie z dyrektywami ministra wojny Gorgeia, co zresztą potwierdził przedstawiciel sztabu naczelnego wodza Paskiewicza: podejmować walkę przy równych siłach, w innym wypadku symulować gotowość bojową i kontynuować odwrót. Wybór najbezpieczniejszy rozmijał się z oczekiwaniami Kossutha, oczekującego powstrzymania Rosjan.

Bezskutecznie usiłował polski generał porozumieć się z pełniącymi wyższe funkcje dowódcze Bemem i Dembińskim, jak również dowódcą IV korpusu, gen. Morem Perczelem $^{57}$. IX korpus stanął w Cegled, gdzie jego komendant usiłował dołączyć do V korpusu gen. Antala Vettera (6 VII). Po nieudanej próbie dymisji Wysocki kontynuował odwrót Armii Górnych Węgier ku Szegedynowi, Legion Polski w tylnej straży. Czasowo Wysocki zmuszony był podporządkować się gen. Perczelowi, dowódcy Armii Nadcisańskiej (Legion Polski, IX korpus, X korpus rezerwowy) osłaniającej środkową linię Cisy przed Rosjanami.

Zespół kawaleryjski (3 szwadrony 5 pułku huzarów, 4 szwadrony I7 pułku huzarów, 2 szwadrony pułku huzarów im. Karolyego, 2 szwadrony huzarów pułków im. Palatyna i Mikołaja, sześciofuntowa bateria konna, 2 małe pułki polskich ułanów i trzyfuntowa półbateria konna Legionu Polskiego tj. I80o huzarów, 600 polskich ułanów) pod formalną komendą gen. Lazara Mesarosa ${ }^{58}$, prowadząc rozpoznanie na linii komunikacyjnej głównej armii rosyjskiej starł się pod Tura (20 VII) z konnicą gen. Aleksandra Tołstoja (pułk

54 E. Kozłowski, Legion Polski, s. 247.

55 A. Szmyt, Generał Józef Wysocki, s. 169; E. Kozłowski, Legion Polski, s. 244-246, 255.

56 E. Kozłowski (Legion Polski, s. 257, 259, 261, 262) sugeruje, że Rosjanie nie planowali pościgu, przeszacowując jego siły; symboliczne próby oporu pod Cernevicsa 19 VI, pod Lemes-Somos 23 VI - por. W. Ramming, Der Feldzug in Ungarn und Siebenburgen in Januar 1849, Pest 1850, s. 176; J. Bułharyn, Rys wojny, s. 284; A. Danzer, Dembiński in Ungarn, t. 2, s. 89; J. Wysocki, Pamiętnik, s. 87; N. Scerbatov, General feldmarsal knjaz Paskevic, ego zizn i dejatelnost, St. Petersburg 1899, t. 5, s. 148-184, t. 6, s. 87-88, 93.

57 W. Ramming, Der Feldzug, s. 184; E. Kozłowski, Legion Polski, s. 264.

58 Obecni byli gen. Dembiński, Dessewffy i Perczel. J. Bułharyn, Rys wojny, s. 304; A. Danzer, Dembiński in Ungarn, t. 2, s. 130-136; W. Poniński, Wspomnienia, s. 31; J. Grabowiecki, Moje wspomnienia, s. 183. 
jelizawetgradzki w. księżnej Olgi, pięć szwadronów 4 pułku króla Hannoweru, dwa szwadrony charkowskiego pułku lansjerów, dwie sotnie Kozaków, 2 baterie konne) w jedynym podczas całej wojny boju kawaleryjskim. Rosjanie byli nieco liczniejsi i posiadali więcej dział większego kalibru. Polskie pułki tworzyły prawe skrzydło, wiążąc huzarów hanowerskich i trwając pod ogniem nieprzyjacielskiej artylerii ${ }^{5}$. Zamieszanie w szeregach rosyjskich, spowodowane przez huzarów węgierskich, zahamowało przybycie 5 dywizji piechoty gen. Iwana Labincowa z ciężką baterią artylerii konnej. Jako szeregowiec pułku legionowych ułanów walczył tutaj Karol Kalita. Efektem starcia mimo porażki miało być zapobieżenie wysłaniu przez rosyjską komendę główną sił zbrojnych przeciwko armii węgierskiej cofającej się z Wacowa ${ }^{60}$. Na przełomie lipca i sierpnia I849 r. gen. Wysocki dowodząc piechotą IV i IX korpusu prowadził ich odwrót spod Szegedyna ${ }^{6 \mathrm{I}}$.

Gen. Henryk Dembiński ponownie zawiadujący całością oddziałów insurekcyjnych, co faktycznie sprowadzało się do skoncentrowanej pod Szegedynem oraz rozproszonej po Baczce i Banacie Armii Południowej (36,5 tys. ludzi, 87 dział), nakazał wycofywanie się bez walki, na co wpływ miała szczupłość potencjału militarnego, a także przekroczenie Cisy przez I korpus Schlicka i podejście III korpusu bana Jelacica na południe od Segedyna ${ }^{62}$.

Polscy legioniści, broniąc przeprawy na Cisie pod Szoreg, dokonali kontrataku (4 sierpnia). Rzucony z 2 kompaniami piechurów i półszwadronem huzarów oraz 2 działami na przyczółek mostowy w widłach Cisy i Maruszy Zygmunt Jordan przeciwdziałał desantowi zespołu gen. Juliusa von Haynaua ${ }^{63}$. Io pluton, którym dowodził ppor. Zygmunt Miłkowski, zmusił do odwrotu wypełnioną Austriakami tratwę, najprawdopodobniej raniąc przewodzącego straży przedniej wroga (4 kompanie strzelców, bateria rakietników) gen. Ludwiga von Benedeka, feldm. Franza Liechtensteina i ex-ministra wojny Franza Cordona ${ }^{64}$. Chociaż Dembiński podesłał Jordanowi batalion Czernika, a IX korpus skierował na groblę, pod silnym ostrzałem i naciskiem nieprzyjaciela zmuszony był wydać głównym siłom rozkaz do odwrotu ${ }^{65}$. Pozostawiony z garstką ludzi Jordan, nie otrzymawszy wsparcia, nie mógł powstrzymać ani budowy polowego mostu, ani przeprawy przez rzekę. Według B. Szyndlera Austriacy postawili most na Maruszy, co groziło obrońcom okrążeniem. W Szoreg 2 dywizje piechoty z 40 działami i kawalerią stawiały opór zmasowanym atakom i ostrzałowi. Podjęto szarże huzarów i polskich ułanów, lecz po przygnieceniu koniem rannego Dembińskiego rozpoczęto odwrót z wału przeciwpowodziowego i grobli koło Nowego Segedyna (5-7 sierpnia), ze znaczącą rolą polskiej jazdy Ponińskiego ${ }^{66}$.

7 sierpnia naczelnym wodzem węgierskich sił zbrojnych został mianowany gen. Józef Bem. Wojsko zamiast ku Aradowi, siedzibie rządu rewolucyjnego, podążyło ku Temesvarowi, gdzie nastąpiło decydujące o losach zrywu starcie (9 sierpnia I849 r.). Armia rewolucyjna

59 I. Kovacs, Nieznani polscy bohaterowie, s. 143-144; J. Bułharyn, Rys wojny, s. 305-306; K. Kalita, Ze wspomnień, s. 246; W. Poniński, Wspomnienia, s. 53.

60 I. Kovacs, Nieznani polscy bohaterowie, s. 142-144.

61 E. Kozłowski, Legion Polski, s. 276; I. Grabowiecki, Moje wspomnienia, s. 185.

62 E. Kozłowski, Legion Polski, s. 277; B. Szyndler, Henryk Dembiński, s. 285; W. Zamoyski, Jenerał Zamoyski 1803-1868, Poznań 1930, t. 5, s. 242-243; S. Schnur-Pepłowski, Polacy i Wegrzy, s. 266.

63 E. Kozłowski, Legion Polski, s. 278.

64 E. Kozłowski, Legion Polski, s. 277; Z. Miłkowski, Od kolebki, t. 1, s. 346-349.

65 B. Szyndler, Henryk Dembiński, s. 281 i n.; A. Jeziorański, Pamiętniki jenerała, s. 182.

66 B. Szyndler, Henryk Dembiński, s. 285-286. 
(IV korpus gen. Richarda Guyona, IX Wysockiego/Dessewffyego z ok. Io tys. ludzi i 20 dział w środku linii frontu; X korpus płk. Galla i gen. Kmettyego, przy części V korpusu Vecseya w rezerwie i niewielkiej ariergardzie) w ok. 55-6o tys. żołnierzy i Ioo-I64 dział zmierzyła się z 28-30-tysięcznymi siłami koalicyjnymi gen. Juliusa von Haynau (III korpus gen. Georga Ramberga, IV ks. Franza Lichtensteina, dywizja kawalerii gen. Karla von Gimborna-Wallmodena, rosyjska dywizja gen. Fiodora Panjutina, $194 \mathrm{działa})^{67}$. Bitwę rozpoczął silny węgierski ostrzał artyleryjski w centrum frontu. 8 szwadronów huzarów z korpusu gen. Kmettyego zaatakowało z zamiarem obejścia południowego skrzydła przeciwnika. Wtedy gen. Haynau wykorzystał rezerwową artylerię oraz dywizję gen. Paniutina do czołowego ataku na korpus gen. Dessewffyego. Prawe skrzydło węgierskie, czyli korpus gen. Guyona, zostało okrążone przez dywizje gen. Antona Herzingera i brygadę gen. Eduarda Siegenthala. Na prawej flance IX korpusu usytuowany był Legion Polski, w środku półbateria konna, na lewo przy kamiennym moście 3 batalion dowodzony w zastępstwie chorego Władysława Englerta przez szefa jednej z kompanii, Franciszka Horodyńskiego, natomiast dwa pułki lansjerów wdały się w bój z pułkiem Schwarzenberg ${ }^{68}$. Do ostatka trwała obrona szosy maradzko-temesvarskiej pod Szentadras. Legionowi piechurzy osłaniali węgierską piechotę i powstrzymywali napór 3 szwadronów rosyjskich z artylerią. Adiutantem Naczelnego Wodza został w tej fazie kampanii Jordan, za udział w obronie przyczółka nadcisańskiego i w bitwie temesvarskiej awansowany na majora i odznaczony Orderem Zasługi II klasy. Jednym z kilkunastu kawalerów Orderu został także kpt Józef Jagmin.

Nie każdy Polak zaangażowany w działania zbrojne na Węgrzech trafiał do formacji Wysockiego. Przypomnijmy gen. Józefa Bema, a w cieniu herosa madziarskich walk narodowowyzwoleńczych znajdziemy asystujących mu rodaków. Nominację na wodza siedmiogrodzkich sił zbrojnych bohater Ostrołęki i Wiednia otrzymał 29 listopada I848 r. ${ }^{69}$ Podczas kampanii zimowej (I8 grudnia I848-26 marca I849 r.) Bem operował ok. I2,5-tysięczną Armią Górnego Siedmiogrodu (I brygada mjr. Ignaca Riczko - I40o żołnierzy wojsk regularnych, 3 tys. gwardzistów, 75 konnych i 6 dział; 2 brygada ppłk. Janosa Czetza - I650 piechurów liniowych, 1900 gwardzistów, 900 jeźdźców i Io dział, 3. pod własną komendą - 2300 piechoty liniowej, 900 gwardzistów, 4IO szabel i 8 dział). Austriacki feldmarszałek Anton Puchner komenderował II batalionami piechoty liniowej i 7 pogranicznymi, I6 szwadronami konnicy (I3650 osób i I8 dział), a choć mógł odwoływać się do partyzantki rumuńskiej, faktycznie korzystał z I5-I6 tys. żołnierzy ${ }^{70}$. Ochotnikami u Bema byli m.in. Narcyz Figietty, uczestnik kampanii siedmiogrodzkiej oraz Władysław Józef Rucki (Drucicki), który uciekł na Węgry po galicyjskich wydarzeniach I846 r., najpierw przebywał w szeregach transylwańskich honwedów, po czym przeszedł w stopniu ppor. do polskiego legionu siedmiogrodzkiego ${ }^{71}$.

\footnotetext{
67 Nie licząc niezaangażowanego korpusu Schlicka. E. Kozłowski, Gen. Józef Bem, s. 564; tenże, Legion Polski, s. 283; W. Ramming, Der Feldzug, s. 343-344; 347; R. Kissling, Die Revolution im Kaisertum, t. 2, s. 258.

68 E. Kozłowski, Legion Polski, s. 283-285; tenże, Gen. Józef Bem, s. 564-567; W. Poniński, Wspomnienia, s. 58, 61; J. Wysocki, Pamiętnik, s. 122-123; A. Jeziorański, Pamiętniki jenerała, s. 84-87; Z. Miłkowski, Od kolebki, t. 1, s. 355.

69 E. Kozłowski, Gen. Józef Bem, s. 294.

70 Ibidem, s. 325-330.

71 J. Sokulski, Władysław Józef Rucki (Drucicki) (1815-?), PSB, t. 5, Kraków 1939-1946, s. 397-398. O Legionie siedmiogrodzkim w historiografii pisali E. Kozłowski (Gen. Józef Bem, s. 469-475), J. Grobicki (Formacje kawalerii polskiej na obczyźnie po roku 1831, „Przegląd Kawaleryjski”, 1927, s. 423), a także D. Kacnelson i I. Kovacs, Pamiętniki Edmunda Ślaskiego a legion polski w Siedmiogrodzie, ,Akcent”, nr 2-3, 1992, s. 316-330.
} 
Kilkunastotygodniowe zmagania zbrojne przedstawiały się następująco: I8 grudnia austriacki płk Urban, nazajutrz wspólnie z gen. Augustem Wardenerem odbył bitwę pod Csucsa $\mathrm{z}$ brygadą mjr. Riczko ${ }^{72}$. Austriackie natarcie przeciw brygadzie Czetza miało miejsce pod Zsibo i Szurduk (I9-20 grudnia), a pod Des rozpoczęły się operacje brygady Bema (22 grudnia). Zajęcie transylwańskiej stolicy Kolozsvar/Cluj przez Bema (25 grudnia) zakończyło I fazę walk ${ }^{73}$.

2 stycznia I849 r. gen. Bem wkracza do miejscowości Beszterce (Bistrica, Bystrzyca), aby nazajutrz po bitwie pod Tihuca wyprzeć Urbana za Karpaty, a nawet przeprowadzić wypad na Bukowinę ${ }^{74}$. I3 stycznia polski wódz jest w Marosvasarhely, centralnym ośrodku Szeklerów, węgierskich górali z północno-wschodniego Siedmiogrodu ${ }^{75}$. I7 stycznia przynosi zwycięstwo pod Galfalva, ${ }^{76}$ po czym ,apo Bem” maszeruje na drugą stolicę transylwańską, Sybin (Nagyszeben), gdzie toczy zakończoną odwrotem bitwę z Puchnerem (2I stycznia) ${ }^{77}$.

Zaczyna się tracenie inicjatywy: jeszcze pod Szelindek - rozbicie austriackiej brygady gen. Kallianiego (24 stycznia) $)^{78}$, ale już 4 lutego pod Vizakną austriacko-rosyjski zespół bojowy (ponad 8 tys. żołnierzy) zwycięża 3 tys. węgierskich przeciwników, a 5-7 lutego trwają walki pod Szaszsebes i Szaszvaros, gdzie odważny szturm kończy się uporządkowanym odwrotem, dalej dziesięciokrotna przewaga sił cesarskich daje dotkliwie znać o sobie ${ }^{79}$. Odwrócenie fortuny następuje pod miejscowością Piski na brzegu Sztrigy (9 lutego). Brygady Czetza i Kemenyego (ok. 2 tys. piechoty) zmagały się z grupą Puchnera, dywizją Kallianyego i partyzantką rumuńską (ok. 7 tys. żołnierzy). Wtedy padają słynne słowa Bema: Most stracony i Siedmiogród stracony. Kiedy Austriacy przeprawiają się na zachodnią stronę rzeki uderzają na nich Czetz i batalion Mariassy, Bem odcina przeciwnika ześrodkowanym na moście ogniem artyleryjskim, rzuca honwedów do ataku, odzyskuje most i zmusza Puchnera do odejścia ${ }^{80}$. Zwycięzca zajmuje z marszu Medgyes (Io lutego).

Pod koniec roku I848, po zdobyciu Kolozsvaru rozpoczęły się prace organizacyjne nad powołaniem legionu z polskich ochotników z Galicji, legionistów skłóconych z Wysockim lub nieprzyjętych, z jeńców austriackich, a także rosyjskich, uzupełnionego przez Ukraińców, Słowaków i Cyganów. Przeniesione zostały do położonych przy granicy galicyjskiej Beszterce $^{81}$. Pod koniec stycznia jednostka liczyła 200, a przed wiosenną ofensywą austriacką rozrosła się niemal do 400 osób $^{82}$.

Odwrót brygady płk. Riczki ( 3 batalion pułku „Sandor”, 32 batalion honwedów, 4 kompanie legionu polskiego, jazda - 2 szwadrony huzarów, zalążki jazdy polskiej, 6 lekkich dział - ok. I50o ludzi) ${ }^{83}$ osłaniały oddziały polskiej piechoty podczas ofensywy (II-I7 lutego

72 E. Kozłowski, Gen. Józef Bem, s. 337-340.

73 Ibidem, s. 344-347.

74 Ibidem, s. 351-357.

75 Ibidem, s. 366.

76 Ibidem, s. 367-372.

77 Ibidem, s. 372-381.

78 Ibidem, s. 383-387.

79 Ibidem, s. 399-402.

80 E. Kozłowski, Gen. Józef Bem, s. 409-417.

81 L. Russjan, Polacy i sprawa polska, s. 131; E. Kozłowski, Generał Józef Bem, s. 473; I. Kovacs, Józef Bem. Bohater wiecznych nadziei, Warszawa 2002, s. 128; W. Rucki, Z pamiętników żolnierza, s. 107.

82 E. Kozłowski, Generał Józef Bem, s. 472; L. Russjan, Polacy i sprawa polska, s. 122, 131.

83 E. Kozłowski, Generat Józef Bem, s. 422. 
I849 r.) części korpusu płk. Karola Urbana i gen. Ignaca Malkovskiego (7 kompania piechoty, szwadron jazdy, $1 / 2$ baterii dział + batalion piechoty - ok. I300 żołnierzy) z Bukowiny na północno-wschodni Siedmiogród, z decydującą bitwą pod Kiralynemeti i odwrotowym bojem pod Szeretfalva ${ }^{84}$. Uczestniczyły w kontrofensywie $z$ udziałem Bema (23-27 lutego I849 r.) wiodącego 2 bataliony honwedów, 3 bataliony Szeklerów, 4 szwadrony huzarów i I2 dział i zmuszającego płk Urbana do bitew pod Zsoszeny i Borgoprund (26 lutego), następnie do opuszczenia Siedmiogrodu ${ }^{85} .2$ marca ma miejsce nierozstrzygnięta bitwa Czetza i Bema pod Medgyes, obaj podążają do Segesvar, zamierzając utrzymać linię rzeki Nagykukullo ${ }^{86}$.

Dysponując IO,5 tys. żołnierzy i 30 działami inicjuje gen. Bem przy wsparciu brygady ppłk. Bethlena uderzenie na Sybin, czyli 2 bitwę o miasto (II III) z 5-tysięcznym garnizonem gen. Skariatina (piechota rosyjska, 2 bataliony austriackie i 2 baterie artylerii, milicja saska), wieńczy szturm II batalionu honwedów na główną bramę miejską ${ }^{87}$. Następuje odwrót korpusu rosyjskiego na Wołoszczyznę, rozwiązanie komitetów saskiego i rumuńskiego, a także dymisja gen. Puchnera. Po wymanewrowaniu gen. Kallianyego przez Czetza 20 marca Braszów jest wolny ${ }^{88}$. 24 marca Bem zostaje mianowany feldmarszałkiem-porucznikiem (marszałkiem polnym), uhonorowany Orderem Wielkim Gwiazdy, z diamentem wyjętym z narodowej relikwii, Korony Świętego Stefana.

Przez kilka tygodni Bem m.in. intensyfikuje starania o polski legion na ziemi siedmiogrodzkiej ${ }^{89}$. Prace zahamowała kampania w Banacie (I6 IV-I6 V), którą Bem przeprowadził z 8 batalionami piechoty, 6-8 szwadronami huzarów i 5 batalionami gwardyjskimi. I7 kwietnia pod Vajszlova bój z 2 batalionami armii habsburskiej rozstrzygnął 78 batalion szeklerski. Zapobieżono połączeniu korpusu gen. Malkovskiego z Wołoszczyzny z Serbami gen. Teodorovica w Baczce, a po zespoleniu z gen. Perczelem zwycięstwo pod Fehertemplom (I2 maja) przypieczętowało poza dwiema twierdzami oswobodzenie Banatu ${ }^{90}$.

Z początkiem lipca do reorganizacji legionu włączył się mjr Leon Czechowski ${ }^{91}$. Przybył na Węgry z końcem maja bądź początkiem czerwca I849 r., jednak nie otrzymał stosownego stanowiska w legionie Wysockiego. Przedostał się do formacji legionowej w Transylwanii, gdzie wszedł do komitetu organizacyjnego z ppłk. Franciszkiem Salezym Łosiem na czele. Awansowany na podpułkownika zadowolił się dowództwem legionowej piechoty (I. batalion i zalążek 2.), a wraz z 270 jeźdźcami i obsadą artylerii polowej stanęło pod bronią 900 ochotników ${ }^{92}$. Innym przybyszem, z pułku Ponińskiego, był Julian Nadmiller. Charakterystyczne, że dyscyplina wojskowa stała tu wyżej niż u Wysockiego. Funkcjonowały obozy

84 F. Bagieński, Wspomnienia starego wołyniaka, Warszawa 1987, s. 99-100; W. Rucki, Z pamiętników żotnierza, S. 107-108.

85 E. Kozłowski, Gen. Józef Bem, s. 474-475.

86 Ibidem, s. 428-433.

87 Ibidem, s. 437-441.

88 E. Kozłowski, Gen. Józef Bem, s. 449.

89 Ibidem, s. 450-452.

90 Ibidem, s. 476-485.

91 M. Tyrowicz, Czechowski Leon, PSB, t. IV, Kraków 1938, s. 314-315; I. Kovacs, Nieznani polscy bohaterowie, s. $186 \mathrm{i} \mathrm{n}$.

92 E. Kozłowski w Zarysie dziejów wojskowości polskiej do 1864 r., red. J. Sikorski, Warszawa 1966, t. 1, cz. 2, s. 471-472, pisał, że Legion zrazu miał 1300 ludzi w batalionie pieszym i pułku jazdy, w lipcu odtworzono batalion i pułk, 1/2 baterii artylerii; I. Kovacs, Józef Bem, s. 204-20; D. Kacnelson, I. Kovacs, Pamiętniki Edmunda Ślaskiego, s. 329 . 
w Sybinie i Besztercach, Samoszujwar stał się centrum organizacyjnym legionowej jazdy ${ }^{93}$, agenci Bema badali nastroje w Galicji i zachęcali tamtejszych woluntariuszy, jako że po zakończeniu operacji siedmiogrodzkiej spodziewano się wypadu za Karpaty. Organizacyjnie wzorowano się na regulaminach austriackich i węgierskich. Obowiązywał mundur biały z karmazynowymi rabatami, kołnierzem i mankietami, czapka i rajtuzy w konnicy karmazynowe z białym lub srebrnym lampasem ${ }^{94}$. Edmund Ślaski, członek lwowskiego legionu akademickiego, należał do aktywnych przyjaciół sprawy węgierskiej, uczestniczył w walkach barykadowych zaduszek lwowskich (2 listopada I848 r.). Pojawił się na ziemi węgierskiej 20 czerwca I849 r. niemal równocześnie z rosyjską armią feldmarszałka Iwana Paskiewicza. Zdążył dotrzeć do formującego się legionu siedmiogrodzkiego, obejmując stanowisko sekretarza zarządu's.

Siły rosyjskie w siedmiogrodzkiej części Korony Św. Stefana latem I849 r. to V korpus gen. Aleksandra Ludersa z wydzieloną grupą gen. Gustawa Hasforda i grupa bukowińska gen. Magnusa Johanna Grotenhjelma (ok. 4I tys. bagnetów, szabel i obsługi dział). Z żołnierzami austriackimi, głównie w słabiej zaangażowanym korpusie gen. Eduarda Clam-Gallasa alianci dysponowali ponad 56 tys. żołnierzy ${ }^{96}$. I9 czerwca korpus Grotenhjelma z austriacką brygadą gen. Springensfelda (13 tys. piechoty, 33 działa) rozpoczął działania przeciw dywizji „Beszterce” płk. Jozsefa Dobaya ( $8 \mathrm{i}^{1} \stackrel{1}{3}$ batalionu piechoty, $2^{1} \frac{1}{2}$ szwadronu jazdy -7838 bagnetów i szabel, $42 \mathrm{I}$ koni i I2 dział), wskutek czego 2 kompanie legionu polskiego (465 ochotników) poniosą znaczne straty osobowe i materiałowe ${ }^{97}$. Pod Borgoprund (22 czerwca) dywizja walczyła z jednostkami grupy gen. Grotenhjelma, tracąc m.in. ciężko rannego komendanta. Nadciągnęła odsiecz gen. Bema z 7 tys. bagnetów i I4 działami (25-28 czerwca) $)^{98}$. Wzmocniona I dywizja pod komendą Bema podjęła kontrnatarcie na przełęcz (26-27 czerwca). Skutecznie przeciwstawiła się po połączeniu z dywizją „Beszterce” 9-II tysięcznej grupie koalicyjnej (I lipca) ${ }^{99}$.

Io lipca legion poniósł pod Besztercami na tyle ciężkie straty (Rucki znajdował się w 2 kompanii I. batalionu polskiego ${ }^{100}$, że formacja obejmowała tylko 60 jeźdźców, zdziesiątkowany I. batalion i 2. wciąż na etapie organizacyjnym. Uzupełniło ją 300 umundurowanych i uzbrojonych byłych jeńców wojennych przysłanych z Szegedynu ${ }^{\text {Ior }}$.

Gen. Bem już z 8,5-tysięcznym wojskiem (w tym polscy legioniści) i 30 działami do 2I lipca oczyścił z nieprzyjaciół Kraj Szeklerów ${ }^{102}$. Wyróżniła się tutejsza „mutacja” polskiego legionu, spośród wyższych oficerów m.in. mjr Tomasz Wierzbicki. Polacy stawali dzielnie 2I lipca pod Szaszregen (Reghin) przeciw koalicyjnym oddziałom składającym się z 7 batalionów pieszych, 5 szwadronów konnicy, 1/2 sotni kozackiej i 23 dział, gdzie mimo

\footnotetext{
93 D. Kacnelson, I. Kovacs, Pamiętniki Edmunda Ślaskiego, s. 325.

94 E. Kozłowski w: Zarys dziejów wojskowości polskiej, s. 474; J. Grobicki, Formacje kawalerii polskiej na obczyźnie, s. 423; J. Szyc, Legiony polskie na Wegrzech, s. 56-57.

95 E. Ślaski, Pamiętnik z czasów rewolucji węgierskiej 1849 r., „Akcent”, 1992, nr 2/3, s. 331, 342-343.

96 E. Kozłowski, Generał Józef Bem, s. 503-510.

97 Ibidem, s.503, 509, 514 i n; I. Kovacs, Józef Bem, s. 194-205; A. Niepokojczyckij, Opisanije wojny w Transsilwanii w 1849 g., Petersburg 1858, s. 301-302, 307; W. Rucki, Z pamiętników, s. 171.

98 E. Kozłowski, Gen. Józef Bem, s. 516-517.

99 Ibidem, Gen. Józef Bem, s. 519.

100 W. Rucki, s. 180-181; E. Ślaski, Pamiętnik, s. 345-346.

101 E. Langie, Pamiętniki niedoli, s. 8.

102 E. Kozłowski, Gen. Józef Bem, s. 536.
} 
ryzyka tyłowego ataku zespołu gen. Władysławowicza ( 2 bataliony piechoty, 2 szwadrony jazdy, 30 kozaków, 6 dział) wyparli obrońców, a zniszczenie mostu było dziełem ariergardy z 4 kompanii legionowych i $4 \mathrm{dzial}^{103}$. Polski legion bit się bardzo dzielnie, ale nasi ułani wspierani ogniem baterii zmuszali go do odwrotu z kazdej pozycji" -odnotowat mimo tego rosyjski sztabowiec polskiego pochodzenia Artur Niepokojczycki ${ }^{\mathrm{104}}$.

$\mathrm{Z}_{3}$ batalionami piechoty, 2 szwadronami jazdy i I baterią artylerii (ok. 2,4-5 tys. żołnierzy i 8 dział) przeprowadził Bem nieoczekiwaną ekspedycję na Mołdawię (2I-25 lipca), podczas której zdobył przełęcz obsadzoną przez rosyjski batalion, jednak ponieważ nie udało się wzniecić zrywu powstańczego, zawrócił do Siedmiogrodu ${ }^{105}$.

Po zajęciu Sybina przez gen. Aleksandra Ludersa (I6 tys. piechoty i 50 dział przeważyło nad 8 tys. honwedów i 26 działami) ${ }^{\text {106 }}$ doszło do kolejnej konfrontacji 6 tys. podkomendnych Bema i I 2 tys. Rosjan 3I lipca pod Segesvar (Szekelykeresztur). Ponieważ zawiodła próba koncentracji powstańczej mimo skutecznego ostrzału artyleryjskiego, od którego poległ gen. Skariatin, odsiecz brygady gen. Engelgarda i manewr oskrzydlający od południa oraz natarcie kozackie od północy spowodowało załamanie obrony. Mimo to nie doszło do połączenia korpusu Ludersa z marszałkiem Paskiewiczem i gen. Haynau. Sytuację wykorzystał Bem, uderzając z 7,5 tys. piechoty i I8 działami po raz trzeci na Sybin, a pokonując brygadę gen. Hasdorfa $(4,5$ tys. żołnierzy), odniósł ostatnie zwycięstwo w skali całej rewolucji (5 sierpnia) ${ }^{107} .6$ sierpnia pod Sybinem rozegrała się ostatnia już batalia. Górujący nad zabudowaniami łańcuch wzgórz obsadziły: środek - artyleria pod osłoną piechoty, cofnięte skrzydła szyku bojowego - jazda, piechota i artyleria, we wsi Nagycsur - kolumna rezerwowa z 4 działami, 6 pieszych batalionów, 500 jeźdźców i I8 dział miało przeciw sobie V korpus Ludersa i osłabioną brygadę Hasforda. Wysiłki obejścia skrzydeł Rosjanie odparli, nacierając na lewe skrzydło i wieś. Bem przypuścił bezskuteczny kontratak, a gdy jego lewe skrzydło rozbiła jazda, centrum zostało odsłonięte. 2 bataliony rosyjskie uderzyły czołowo, przełamując opór obrońców i przypieczętowując klęskę Pod Kistorony rozbite zostały przez ściągającą pokonanych rosyjską konnicę dwa szwadrony polskiego legionu ${ }^{\mathrm{I09}}$. Kręgosłup transylwańskiego zrywu został przetrącony. Bem przekazał dowództwo, udając się na Wielką Nizinę Węgierską ${ }^{\text {IIO }}$.

I3 sierpnia legioniści osłaniali odwrót z Cluj części dywizji kolożwarskiej i resztek dywizji szeklerskiej ${ }^{\text {II }}$. Ślaski i Rucki uczestniczyli z rezerwowym szwadronem ułanów w słynnej szarży ostatniej bitwy na północnym froncie siedmiogrodzkim pod Banffyhunyad (I6 sierpnia), gdzie odrzucono nacierające kolumny rosyjsko-austriackiej dywizji Grotenhjelma. Lansjerzy z oddziału szturmowego Łosia skutecznie odparli przeciwników ${ }^{\text {I2 } 2}$. Polska półbateria artyleryjska, zgodnie $\mathrm{z}$ tradycją Bema pozostawała na przedzie, a w odwrocie

\footnotetext{
103 Ibidem, s. 556.

104 A. Niepokojczycki, Opisanije wojny, s. 165-166.

105 E. Kozłowski, Gen. Józef Bem, s. 539-542.

106 Ibidem, s. 544.

107 Ibidem, s. 549.

108 Ibidem, s. 554-558.

109 I. Kovacs, Polacy w węgierskiej Wiośnie Ludów, s. 303; W. Rucki, Ze wspomnień, s. 203-204, 208.

110 E. Kozłowski, Gen. Józef Bem, s. 553-554.

111 D. Kacnelson, I. Kovacs, Pamiętniki Edmunda Ślaskiego, s. 330; E. Ślaski, Pamiętniki, s. 346.

112 E. Kozłowski, Gen. Józef Bem, s. 475; I. Kovacs, Polscy bohaterowie, s. 186-187; tenże, Polacy w węgierskiej Wiośnie Ludów, s. 304-305; E. Ślaski, Pamiętniki, s. 347-348.
} 
posuwała się ostatnia, budząc uznanie nawet nieprzyjaciół ${ }^{113}$. Dzień po batalii dowódca 2 kompanii I. batalionu, Rucki, trafił do niewoli, skąd niemal natychmiast uciekł"14.

Niedobitki kolożvarsko-seklerskich jednostek na wieść o kapitulacji gen. Gorgeia połączyły się z kunktatorską dywizją płk. Kazinczy’ego. Rosyjski parlamentariusz przyniósł list Gorgeia do towarzyszy broni, z sugestią złożenia broni. Kapitulacja armii siedmiogrodzkiej (24-25 sierpnia) wywołała oburzenie polskich i węgierskich patriotów ${ }^{\mathrm{I5}}$.

Nie ulegając namowom, polski legion rozproszył się dopiero w okolicach Nagybanya. Czechowski przedostał się na Śląsk, skąd w obawie przed wydaniem carowi wyjechał do Paryża, zasilając zwolenników Hotelu Lambert" ${ }^{\mathrm{II}}$. Rucki ukrywał się na Węgrzech aż do Bożego Narodzenia I852 r., a po osądzeniu przez sąd wojenny odbył dwuletnią karę więzienia w Koszycach. Po ponownym krótkim uwięzieniu skierowany został do Galicji ${ }^{117}$.

Niewiele wiadomo o zaangażowaniu Wiktora Dobrosielskiego w wojnę węgierską poza odbyciem po powrocie do Królestwa Polskiego 4-letniej kary pobytu w zamojskiej twier$\mathrm{dzy}^{\mathrm{II}}$. Podobnie było z weteranem Legii Cudzoziemskiej Aleksandrem Matuszewiczem, austriackim ex-oficerem, ppor. Legionu Stanisławem Szumlańskim ${ }^{119}$, późniejszym kapitanem honwedów, przedstawicielem pruskiego korpusu oficerskiego Władysławem Miśkiewiczem czy Leszkiem Wiśniowskim jako urodzonym w Galicji wcielonym do karnej kompanii austriackiej w Komarnie. Nie do końca potwierdzono akces Ignacego Mystkowskiego, uciekiniera za granicę Królestwa Polskiego w czerwcu I848 r. ${ }^{\text {I20 }}$

Choć straty w batalii temeszwarskiej nie były duże, podczas odwrotu zdemoralizowana armia rozproszyła się, a w Lugos zebrało się ok. 50\% stanu wyjściowego ${ }^{121}$. Walery Kozłowski został austriackim jeńcem pod Vilagos, gdzie kapitulował dowódca innej armii, gen. Gorgey. Dezertera z habsburskiego wojska czekało 5-letnie więzienie w twierdzy Munkacz. Legion polski $\mathrm{w}$ ariergardzie ścierał się codziennie $\mathrm{z}$ pościgiem - ostatnia akcja bojowa to osłona przejścia górskiego pod Teregovą przez 2 działa w asekuracji batalionu honwedów ${ }^{122}$. I7 sierpnia Kossuth pożegnał się w Orszowie z legionistami, na wniosek Wysockiego 26 z nich odznaczył Orderem Zasługi III klasy. Uzasadnienie dla mjr. Horodyńskiego za postawę pod Temesvarem brzmi: jako dowódca batalionu [...] stawił czoła najsilniejszemu ostrzałowi armatniemu: straty siegały prawie połowy zasobów jego batalionu, co świadczy chwalebnie o jego niezłomności: podtrzymujac w żolnierzach ducha bojowego zachowat do końca porządek $w$ swoich szeregach, a potem osłaniat odwrót $t^{123}$.

Pomiędzy I8 a 20 sierpnia legioniści opuścili Węgry. Dowódca legii polskiej do narodu węgierskiego wygłosił pożegnalną mowę: Walczyliśmy z wami, wiecie o tym dobrze, nie jako najemnicy, nie dla osobistych widoków, ale $w$ nadziei, że wasze powodzenie $i$ wzięty przez

\footnotetext{
113 A. Niepokojczycki, Opisanije wojny, s. 279.

114 I. Kovacs, Polacy w węgierskiej Wiośnie Ludów, s. 305-309; W. Rucki, Ze wspomnień, s. 210-214.

115 E. Kozłowski, Gen. Józef Bem, s. 557.

116 M. Budzyński, Wspomnienie mojego życia, Poznań 1880, s. 263-265.

117 I. Kovacs, Polacy w węgierskiej Wiośnie Ludów, s. 309; W. Rucki, Ze wspomnień, s. 243.

118 J. Giergielewicz, Wiktor Dobrosielski (1827-1898), PSB, t. 5, Kraków 1939-1946, s. 248-249.

119 Stanisław Szumlański (1818-1866), PSB, t. 49, Kraków 2013-2014, s. 356 J. Wysocki, Pamiętnik, s. 147.

120 M. Bartniczak, Ignacy Mystkowski (1826-1863), PSB, t. 22, Kraków 1977, s. 275-276.

121 E. Kozłowski, Legion Polski, s. 285; Z. Miłkowski, Od kolebki, t. 1, s. 356.

122 E. Kozłowski, Legion Polski, s. 288.

123 I. Kovacs, Nieznani polscy bohaterowie, s. 208-209, 214.
} 
nas w nim udziat stanie się podstawa do walki dalszej, która jest nieustajacym celem życia naszego; do walki o niepodległość Polski, bez której niepodległość Wegier ani się utrzymać, ani do skutku nie da się doprowadzićn ${ }^{124}$.

Epilogiem walk za Wasza wolność i nasza okazał się pobyt I03o byłych legionistów na tureckiej ziemi, internowanych w Widyniu, Szumli i Kutahyi. Wśród czterech generałów był Józef Wysocki, jednak warunek zmiany wyznania odstręczył go od wstąpienia na służbę

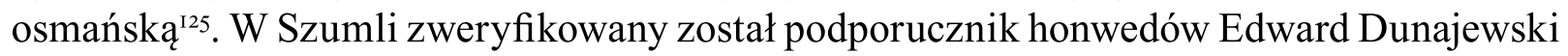
(30 grudnia I849 r,). Internowany w Szumli Karol Kalita po powrocie do Cesarstwa Habsburgów został skazany na 8-miesięczny areszt w Temesvarze, a karę 60 kijów zamieniono na ponowne wcielenie do armii austriackiej. Edmund Ślaski pojmany do niewoli wcielony został do cesarskich sił zbrojnych, dosługując się stopnia nadporucznika Sztabu Generalnego.

Próbę oceny zdobytej przez przyszłych polskich dowódców partyzanckich praktyki bojowej i jej wykorzystania w bojach na własnej ziemi zostanie poświęcona druga część artykułu.

\section{„The Hungarian track”. From Spring of Nations (1848-1849) in the area of Crown Saint Stefan to the Polish Uprisings (1863-1864), Vol. I Summary}

During the Spring of Nations in the lands of the Crown of St. Stefan (I848-I849) traditional ties of friendship, with the possibility of a military confrontation occurring with one, two invaders attracted a large crowd of Polish volunteers for the formation of the Hungarian honveds. About 4,00o Poles were fighting directly in the ranks of the revolutionary army, and enrolled to the national legions under the command of Generals Joseph Wysocki alongside the Transylvanian Army Fieldmarshal Joseph Bem. Among them, about 20 individuals who will be later on commanders of the guerrilla armed troops of the January Uprising (I863I864). For this reason, it is worth recalling the experience that the military group acquired during the battles for the Hungarian Plain, Slovakia, Bukovina, Moldavia, Banat, Backa and Transylvania.

Keywords: Spring of Nation I848-I849 in the Europa; Hungarian Revolution/Uprising against Habsburg dynasty; Polish Legion in the lands of St. Stefan Crown; insurgent leadership cadre

Nota o Autorze: Adam Bulawa, doktor, adiunkt Instytutu Nauk Historycznych Wydziału Nauk Historycznych UKSW, zainteresowania naukowe: historia wojskowości, historia XIX w. Polski i powszechna, losy Polaków poza granicami kraju.

\footnotetext{
124 W. Zamoyski, Jenerał Zamoyski, t. 5, s. 266; J. Wysocki, Pamiętnik, s. 132-133; I.Kovacs, Nieznani polscy bohaterowie, s. 68; M. Wieliczko, Polacy na Wegrzech, Lublin 1977, s. 55.

${ }^{125} \mathrm{Na}$ ten temat pisali m.in. K. Dopierała, Emigracja polska w Turcji w XIX i XX w., Lublin 1988, s. 117-123; A. Lewak, Dzieje emigracji polskiej w Turcji 1831-1878, Warszawa 1935, s. 62-86.
} 